\title{
Nuclear security undervalued
}

\author{
The world's only agency for assuring global standards and security in nuclear installations needs \\ an upgrade. This cannot be done on the cheap.
}

\rceil hink of the International Atomic Energy Agency (IAEA) and images come to mind of intrepid inspectors using the latest James Bond-like techniques to ferret out would-be nuclear proliferators. The reality is considerably less powerful. In theory, for example, mass spectrometry of microparticles has revolutionized the ability of inspectors to detect even tiny amounts of highly enriched uranium. In practice, they not only face a significant backlog of samples, but have to make do with instruments that are often three decades old and have no available spare parts.

And that is assuming that the inspectors have actually found the samples. The agency cannot afford to purchase sufficient commercial satellite imagery, much less possess its own satellite system, so too often it learns of the construction of suspect nuclear facilities from the media, or from non-governmental organizations.

Without a major budget increase for the IAEA, the world will not make the most of a vital player in defending against some of the greatest dangers it now faces. As billions of dollars pour into the expansion of nuclear power, and as more nations seek to join the nuclear club, the IAEA's budget has been flat at around $€ 280$ million (US $\$ 406$ million) for much of the past two decades, despite an increasing workload. This stagnation is the result of a deliberate policy of 'zero real growth' imposed in the late 1980s by the richer members of the IAEA's 144 member states, who wanted to force international agencies to reform and seek external funds.

The agency's role is most deficient in the realm of nuclear security. In 2002, it created a Nuclear Security Fund in the wake of 9/11 to boost its almost non-existent efforts to help secure nuclear materials worldwide, and to detect and prevent nuclear terrorism. But the fund depends on voluntary contributions from member states, and its current annual budget of $€ 15$ million is not only wholly inadequate, it also includes some 'in kind' contributions, and is peppered with national earmarks.

Politicians worldwide claim that they have made nuclear security a priority since $9 / 11$, but they must now translate that promise into action: at least double the IAEA's budget, a ballpark figure already suggested by the agency's director-general, Mohamed ElBaradei. Such a doubling of an already small budget is surely the least that would be consistent with the world's expectations of the agency.

Furthermore, the IAEA's member states should make the Nuclear Security Fund a regular part of the agency's budget, paid for by dues, so that it can be properly planned and staffed. It needs the means to hire and train a sufficient number of experts on nuclear security, to provide the international community with a detailed picture of nuclear security worldwide, and to focus its efforts in areas, such as the former Soviet Union, where they are most needed. It also needs greater powers - at present the IAEA can comment on what it sees as insecure facilities or stockpiles, but has no powers to enforce tighter security measures and upgrades, as these remain national prerogatives.

There is also a greater need for nuclear operators worldwide to openly share security and information among themselves. One model is the World Association of Nuclear Operators, a forum created after the Chernobyl accident to bring together "There is a greater need for nuclear operators worldwide to openly share security and information among themselves." all the players in nuclear power to swap notes and review best safety practices. The US Nuclear Threat Initiative has proposed creating the same sort of forum, a World Institute for Nuclear Security, to discuss security issues. The idea is a valuable one that merits support.

ElBaradei has launched a '20/20 review' to redefine the IAEA's role in a world of expanding nuclear power and new security threats. The IAEA needs to be able to use the best technologies available, including mathematical modelling of material flows in sensitive facilities, and remote sensors, to better monitor diversion of nuclear material. It needs better databases of the fingerprints of illicit material to establish its origins. That will also require a new breed of inspector, less oriented towards checking the quantities of nuclear materials going in and out of facilities, and more detectivelike, more inclined to rock the boat, and above all, better trained in the latest high tech. None of that will come cheap. No one is asking that the IAEA be given a blank cheque, but properly funding our international nuclear-verification system seems to be a bargain insurance policy.

\section{Genetics benefits at risk}

\section{A rogue senator needs to be bypassed.}

7 echnology development guru George Church - aka the information exhibitionist - is playing a salutary social role with his Personal Genome Project. Church is in the process of gathering phenotypic data and sequencing portions of the genomes of ten volunteers, including himself (see page 763). He intends to study how the genes of these people - all but one of whom have revealed their identities - influence their phenotypes, and to make those data public. Church's point is simple: information, including genetic information, can and should be freely available.

Whether or not one agrees with him, society had better be ready to deal with the results of such research, which is occurring against a background of explosive growth in the availability of genetic information. Consider that, in the five-and-a-half months since Nature last opined about this topic (see Nature 448, 969; 2007), the number of 
diseases for which genetic tests are available to patients has grown by $8.4 \%$, to 1,236 .

This makes it all the more urgent that the US Congress enact the Genetic Information Nondiscrimination Act, which would protect people from being discriminated against by health insurers or employers on the basis of their genetic information. The entire scientific and medical community is adamantly supportive of this bill - as is the House, which passed it on a vote of 420:3 last April. In previous Congresses, the Senate has twice passed it unanimously. These are sure signs of an idea whose time has come, given that no less powerful a lobby than the US Chamber of Commerce had twisted arms to try to prevent its passage.

But for seven months now, one senator, Tom Coburn (Republican, Oklahoma), has used a procedural manoeuvre called a 'hold' to prevent the bill from coming to a vote in the Senate. Although Coburn, a practising obstetrician, voted for the bill in past, he is now refusing to budge, knowing full well that if he does lift his hold and allow a vote, this would all but guarantee the bill's signing into law. (President Bush, during a visit to the National Institutes of Health a year ago, urged Congress to pass the bill; his administration also put out a written statement of policy supporting it.)

Coburn has said he won't support the bill without a change that would drive a huge hole through its protections. In essence, he wants to insulate employers from ever being sued for a discriminatory act if an insurer is also culpable in the same situation. To put a human face on it, let's say that Employer X, who is a major client of Insurer $\mathrm{Y}$, asks Insurer Y to make life miserable for Employee Z by, say, denying her coverage based on a genetic predilection for breast cancer in her family. If Coburn had his way, the insurer could be fined, but the employer would be immune from being sued for damages by Employee Z.

It is hard to believe that Coburn is bargaining in good faith, given that he has put holds on at least 86 other pieces of legislation. Nonetheless, if his intention is to protect businesses from an avalanche of frivolous litigation, there's precious little to suggest that this is a serious danger, given the virtual absence of similar lawsuits in the 34 states that have independently enacted laws forbidding genetic discrimination by employers.

There is a way past Coburn. Under Senate rules, Democratic Senate Majority Leader Harry Reid could force the bill to a floor vote by allowing 30 hours of debate on it first. That kind of time is a precious commodity in a highly preoccupied Senate. But it's hard to imagine a more worthy cause for which to make room, or a more important legacy for this Congress - and scientists should tell Reid as much.

Otherwise, the enormous research and clinical progress being made in the nascent era of personalized medicine will come crashing to a halt because people - despite the efforts of George Church - will remain rightly wary of taking genetic tests.

\section{Down on the farms}

\section{Efforts by the Ministry of Defence to block offshore wind farms is at odds with Britain's long-term security.}

W hen the UK government set out its energy policy in the spring of last year, it was heralded as one of the most ambitious programmes in Europe. The government pledged to reduce carbon dioxide emissions from 1990 levels by at least $26 \%$ in 2020 and by $60 \%$ in 2050 .

Wind energy is poised to play a small but critical role in the government's green scheme. Wind power is among the most competitive of all renewable energy sources, and it will help the government to meet near-term goals - most notably, a 10\% reliance on renewable energy by 2010 . At present, there are 2.3 gigawatts of installed capacity in Britain, and current projects in planning could bring that number to 33 gigawatts by 2020 .

That is, if developers can convince the Ministry of Defence (MoD) to let them build. The MoD has opposed wind farms for more than a decade, on and off, on the basis that they interfere with air-defence radars. Construction of turbines requires $\mathrm{MoD}$ approval during the planning stages, and last week the ministry announced that it is blocking four offshore wind farms planned for the North Sea. The farms, it claimed, would interfere with radar stations along the coast.

The MoD's current policies are at odds with those of other European nations that depend on wind energy. Austria, Germany and the Netherlands all require a review of wind farms built within a certain range of military installations, but none have the ministry's blanket policy demanding sign-off on all turbines within any radar line-of-sight. Given that air-defence radar must, by definition, cover the entire coastline, the rule effectively means that the $\mathrm{MoD}$ can block any offshore farm.

Its concerns do deserve consideration. The massive blades of wind turbines have an enormous radar cross-section that can make it more difficult to see behind them. That has led to fears that a low-flying aircraft or cruise missile might be able to use the farms as cover for a stealth attack. More critically, spinning blades interfere with a radar's Doppler system, creating false contacts and blinding operators to the area above the farm. Ongoing studies by the MoD and the US Department of Defense show that the overall effect depends both on the position of the farm and the type of radar used.

But there is no reason to think that the radar problem is insurmountable. Signal-processing hardware and software now in development should be able to remove a part of the radar 'clutter' from the area around wind farms. A simpler, though more costly, solution would be the strategic placement of a secondary radar that could either look behind the farms or above them. These solutions are not thought to be prohibitively expensive. Developers, eager to see their turbines turn on, have even expressed a willingness to share in the cost of some necessary upgrades.

The mission of the MoD is to defend the United Kingdom and its interests. In the modern world, the threat of climate change is as real as any military or terrorist threat, and energy supply is a critical aspect of national security.

The technical issues are real, but there is every reason to believe that they can be dealt with using technology that either already exists or can be developed in the near term. It is time for the ministry to end its war with wind-power developers and adopt a more cooperative spirit. 